УДК 616.126-002-02-089

\title{
Клініко-морфологічні взаємоз'язки поєднання прокаріотів із грибковою мікрофлорою в патогенезі інфекційного ендокардиту
}

\author{
Крикунов О. А., Захарова В. П., Буряк Р. В., Колтунова Г. Б., Руснак А. О., \\ Хмелевський А. М.
}

ДУ «Національний інститут серцево-судинної хірургії імені М. М. Амосова НАМН» (Київ)

\begin{abstract}
Особливістю інфекційного ендокардиту (IE) мікотичного генезу є маніфестація захворювання на фоні значного ушкодження імунологічного стану хворих, у тому числі й унаслідок терапії кортикостероїдами або цитостатиками. Ще більше ускладнює лікування IE поєднання грибкової мікрофлори з мікроорганізмами групи ESCAPE. Мета роботи - дослідити клінічні особливості поєднання прокаріотів із грибковою мікрофлорою в патогенезі IE. Матеріали та методи. Основу даного дослідження становлять клінічні дані 94 хворих на активний інфекційний ендокардит, які пройшли обстеження та лікування в Національному інституті серцево-судинної хірургії імені М. М. Амосова НАМН з 01.01.2014 по 01.12.2016 р. Результати та їх обговорення. Частота реєстрації грампозитивних і грамнегативних мікроорганізмів становила 84 (89,4\%) та $10(10,6 \%)$ випадків відповідно. Поєднання прокаріотів та еукаріотів у патогенезі IE зареєстровано в 18 $(19,1 \%)$ випадкахв. Найбільш часте приєднання грибкової мікрофлори спостерігалось у випадках інфекційного ендокардиту, спричиненого Enterococcus spp., - 42,9\% випадків. Із 22 випадків госпітального IE у 8 $(36,4 \%)$ випадках спостерігався міцелій у клапанних структурах $(\mathrm{X} 2=4,956, \mathrm{p}=0,026)$.
\end{abstract}

Ключові слова: інфекційний ендокардит, грибкова мікрофлора, прокаріоти.

Сучасними тенденціями в епідеміології інфекційного ендокардиту (IE) є значне збільшення ролі нозокоміальних факторів у процесі первинного інфікування хворих та розширення спектру збудників захворювання, зростання резистентності мікроорганізмів до сучасних антибактеріальних засобів. Ці фактори разом можуть впливати на патоморфоз IE, ускладнити діагностику і тим самим погіршити прогноз захворювання. У клінічній практиці найбільш складними в діагностиці та лікуванні є випадки IE, спричиненого грибковою мікрофлорою. В мікробіологічному спектрі збудників IE частка грибкової мікрофлори становить 10\%, з летальністю більше $50 \%$ [1]. У хворих з імплантованими штучними клапанами серця та водіями ритму IЕ грибкової етіології зустрічається в 2-10\% випадках.

Особливістю IЕ мікотичного генезу є маніфестація захворювання на фоні значного ушкодження імунологічного стану хворих, у тому числі й унаслідок терапії кортикостероїдами або цитостатиками. Крім того, розвитку даного захворювання сприяє нераціональне використання антибактеріальних препаратів із формуванням синдрому персистенції інфекції, імуносупресії та катаболізму. Успіх консервативного лікування захворювання фунгіцидними препаратами завжди залишається сумнівним, оскільки для його досягнення необхідне повне знищення всіх еукаріотичних клітин грибкової мікрофлори $[1,3,5,7]$.

Ще більше ускладнює лікування IE поєднання грибкової мікрофлори з мікроорганізмами групи ES-
САРЕ, тим більше що збудники захворювання синтезують біоплівки. В умовах утворення біоплівки у вогнищах інфекції різноманітність взаємовідносин типових збудників ендокардиту (стафілококів, стрептококів, ентерококів) з грибковою мікрофлорою може зростати шляхом як антагонізму, так і синергізму. На сьогодні найбільш раціональним підходом до лікування IE грибкової етіології $є$ комбінація хірургічного методу лікування з фунгіцидною терапією $[2,4,6,8,9]$.

Мета роботи - дослідити клінічні особливості поєднання прокаріотів із грибковою мікрофлорою в патогенезі IE.

Матеріали та методи. 3 метою дослідження особливостей клінічного прояву та лікування IE був проведений порівняльний аналіз даних анамнезу, демографічних показників, результатів лабораторних та інструментальних методів дослідження між групами хворих, у яких був відсутній (перша група) або наявний (друга група) міцелій грибкової мікрофлори в інтраопераційному матеріалі. Основу для систематизації даних про збудника IE становили такі дослідження: 1) трикратне бактеріологічне дослідження венозної крові до призначення антибіотикотерапії при госпіталізації хворих; 2) бактеріологічне дослідження інтраопераційного матеріалу; 3) гістологічне дослідження інтраопераційного матеріалу. IE в усіх випадках був визначений як активний при позитивних результатах бактеріологічних досліджень крові і/або інтраопераційного матеріалу та наявності синдрому системної запальної відповіді. 
3 метою підтвердження діагнозу IE і дослідження патогенезу захворювання проводилося морфологічне дослідження інтраопераційного матеріалу. Після макроскопічного опису видалених клапанів їх фіксували в $10 \%$ нейтральному розчині формаліну. Половину кожного фрагмента направляли на виготовлення заморожених зрізів, пофарбованих гематоксиліном і еозином, а також суданом III та IV для виявлення жировмісних структур. Із іншої половини фрагмента виготовляли парафінові зрізи з подальшим фарбуванням їх гематоксиліном i еозином, пікрофуксином по Ван Гізону, фукселіном по Вейгерту та методом MSB у модифікації Зербіно-Лукасевича для виявлення фібрину різного ступеня зрілості.

Первинний IE був визначений у випадках виникнення інфекційного процесу на анатомічно нормальних і неушкоджених іншими захворюваннями клапанах серця. Вторинний IE був визначений при виявленні інфекції на вже ушкоджених клапанах серця внаслідок або вроджених аномалій (двостулковий аортальний клапан, дисплазія хордального апарату мітрального клапана), або набутих захворювань клапанних структур (ревматизм, дегенеративні зміни).

Госпітальний IE діагностували, коли захворювання виникало внаслідок інвазивних діагностичних або лікувальних маніпуляцій, які проводилися протягом останніх двох місяців перед виникненням симптоматики захворювання, та у випадках захворювання, які виникли в стаціонарі через 48 годин після госпіталізації хворого. Крім того, до госпітального IЕ відносять випадки раннього IE протезованого клапана серця (протягом перших 6 місяців після хірургічного втручання), що було підтверджено результатами периопераційних бактеріологічних досліджень крові і тканин, ЕхоКГ-даними, які вказують на наявність вегетації або дисфункції протезу, та/або патоморфологічними ознаками активного інфекційного процесу.

Результати та їх обговорення. Основу даного дослідження становлять клінічні дані 94 хворих на активний

\section{Таблиця 1}

Мікробіологічний спектр збудників IE

\begin{tabular}{lcc} 
Збудник & $\mathbf{n}$ & $\mathbf{\%}$ \\
\hline Staphylococcus spp. & 45 & 47,8 \\
\hline Streptococcus spp. & 10 & 10,6 \\
\hline Enterococcus spp. & 28 & 29,8 \\
\hline Micrococcus spp. & 1 & 1,1 \\
\hline Pseudomonas spp. & 5 & 5,3 \\
\hline Klebsiella spp. & 1 & 1,1 \\
\hline Serracia spp. & 1 & 1,1 \\
\hline Esherichia coli & 2 & 2,1 \\
\hline Sternotrofomonas spp. & 1 & 1,1 \\
\hline Paзом & 94 & 100
\end{tabular}

інфекційний ендокардит, які пройшли обстеження та лікування в Національному інституті серцево-судинної хірургії імені М. М. Амосова НАМН з 01.01.2014 по 01.12.2016 p. Діагноз IЕ був встановлений відповідно до патоморфологічних і клінічних критеріїв Duke Endocarditis Service (1994р.). Середній вік досліджуваних

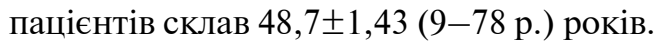

Перший основний критерій діагностики IE передбачає виявлення та ідентифікацію збудників захворювання. Частота реєстрації грампозитивних і грамнегативних мікроорганізмів становила $84(89,4 \%)$ та 10 $(10,6 \%)$ випадків відповідно. Із грампозитивних мікроорганізмів найбільшу частку склали Staphylococcus spp. $(47,8 \%)$ та Enterococcus spp. (29,8\%). Із грамнегативних мікроорганізмів найбільш часто реєструвалася Pseudomonas spp. - 5 (5,3\%) спостережень (табл. 1).

Другий основний критерій діагностики IE включає ЕхоКГ-візуалізацію вегетацій, внутрішньосерцевих абсцесів і ступінь інфекційної деструкції клапанів серця. В усій групі спостереження переважають ураження аортального клапана (AK) - $53(56,4 \%)$ випадки, із них IE нативних і протезованих клапанів серця був у $50(53,2 \%)$ i $3(3,2 \%)$ спостереженнях відповідно (табл. 2). Ураження мітрального клапана (МК) виявлене у $42(46,7 \%)$ пацієнтів, з яких у $2(2,1 \%)$ випадках інфекційний процес виник на фоні імплантованих штучних клапанів серця.

Інфекційний ендокардит клапанів правих відділів серця виявлений у $10(10,6 \%)$ випадках, з яких ізольоване ураження тристулкового клапана (ТК) і клапана легеневої артерії було у $8(8,5 \%)$ випадках і $1(1,1 \%)$ випадку відповідно. Додатково в одного $(1,1 \%)$ пацієнта ураження ТК виникло на фоні імплантованого штучного водія ритму серця (ШВРС). У 33 спостереженнях $(35,1 \%)$ IE клапанів серця був ускладнений формуванням внутрішньоміокардіальних абсцесів: 25 (26,6\%) випадків при IE

\section{Таблиця 2}

Варіанти інфекційного ураження клапанного апарату серия

\begin{tabular}{lcc} 
& \multicolumn{2}{c}{$\mathbf{N = 9 4}$} \\
\cline { 2 - 3 } Види клапанних уражень & $\mathbf{n}$ & \% \\
\hline Інфекційний ендокардит АК: & 53 & 56,4 \\
- нативний клапан & 50 & 53,2 \\
- протезований клапан & 3 & 3,2 \\
\hline Інфекційний ендокардит МК: & 42 & 46,7 \\
- нативний клапан & 40 & 42,6 \\
- протезований клапан & 2 & 2,1 \\
\hline Інфекційний ендокардит & & \\
клапанів правих відділів серця: & 10 & 10,6 \\
- нативний ТК & 8 & 8,5 \\
- нативний ТК на фоні шВРС & 1 & 1,1 \\
- клапан легеневої артерії & 1 & 1,1 \\
\hline Абсцес фіброзного кільця: & \multicolumn{2}{c}{} \\
- АК & 25 & 26,6 \\
- МК & 8 & 8,5
\end{tabular}


AK та 8 (8,5\%) - при IE MK. При ураженнях клапанів правих відділів серця абсцеси виявлені не були.

Відповідно до переліку другорядних критеріїв діагностики IE Duke University (1994) були розглянуті фактори ризику виникнення захворювання, наявність системної запальної відповіді (СЗВ), судинні (емболічні) ускладнення та імунопатологічні прояви. Крім того, в якості другорядного критерію нами були розглянуті дані бактеріологічного та мікроскопічного аналізу інтраопераційного матеріалу.

Вихідна патологія, яка виступала фактором ризику виникнення IE нативних клапанів, включала: ревматичні вади серця $-7(7,4 \%)$ випадків, вроджені аномалії клапанних структур - 15 (16,0\%) випадків, незапальні дегенеративні ураження клапанів - 52 (55,3\%) випадки. Крім того, в якості фактору ризику виникнення IE внаслідок бактеріємії та розвитку набутого імунодефіциту ми розглядали наявність ін'єкційної наркоманії, яка в нашому дослідженні склала 8 (8,5\%) спостережень.

До нашого дослідження увійшли пацієнти, які відповідали критеріям активного IE, тобто мали позитивні бактеріологічні дослідження крові та ознаки СЗВ. Додатковими показниками для характеристики запального процесу були рівні С-реактивного протеїну та прокальцитоніну. Середнє значення температури тіла при госпіталізації становило $38,3 \pm 0,8 \mathrm{C}^{\circ}$ $\left(37,9-39,4 \mathrm{C}^{\circ}\right)$, що супроводжувалося тахікардією $89,7 \pm 16,8$ уд./хв. (60-150 уд./хв.). Також було виявлено лейкоцитоз - $11,1 \pm 4,7 \times 10^{9}\left(2,2 Ч 10^{9}-26,4 \times 10^{9}\right)$ з паличкоядерним зсувом - 17,8 $\pm 8,1 \%(14,0-37,6 \%)$ та підвищенням ШОЕ $-23,6 \pm 10,1$ мм за год. (12,0-79,0 мм за год.). Рівні С-реактивного протеїну та прокальцитоніну становили $64,2 \pm 47,3$ мг/л (4,0-37,6 мг/л) та $7,6 \pm 2,4$ нг/мл (0,06-10,0 нг/мл) відповідно.

Емболічні ускладнення IE були зареєстровані в 12 $(12,8 \%)$ випадках: емболія судин головного мозку діагностована у $3(3,2 \%)$ хворих, емболія селезінкової артерії - у 2 (2,1\%), емболія ниркової артерії - в $1(1,1 \%)$, емболія периферичних артерій кінцівок - у $3(3,2 \%)$ спостереженнях, множинні емболії судин великого кола кровообігу - в $1(1,1 \%)$ випадку. Емболії судин малого кола кровообігу реєструвались у $2(2,1 \%)$ пацієнтів.

До імунопатологічних проявів IE, що свідчать про ураження нирок, відносили ознаки вогнищевого та дифузного гломерулонефриту - 70 (74,5\%) випадків. Середні рівні сечовини та креатиніну становили $8,3 \pm 0,8$ ммоль/л та 110,3 $\pm 6,5$ мкмоль/л відповідно. Замісної ниркової терапії потребувало $2(2,1 \%)$ хворих. При вірусологічному дослідженні крові антигени до вірусного гепатиту В та С були виявлені в $8(8,5 \%)$ та 16 $(17,0 \%)$ випадках відповідно. Антитіла до ВІЛ виявлені в $1(1,1 \%)$ спостереженні.

Усі хворі прооперовані в умовах системної гіпотермії $\left(30{ }^{\circ} \mathrm{C}\right)$ із застосуванням кристалоїдного кардіоплегічного розчину «Кустодіол» $(30$ мл/кг). Хірургія аорталь- ного клапана виконана у $53(56,4 \%)$ хворих, при цьому в $25(26,6 \%)$ випадках проведена пластика абсцесу фіброзного кільця АК. Хірургія мітрального клапана була виконана в $42(44,7 \%)$ спостереженнях і включала протезування MK - 25 (26,6\%) випадків, реконструкцію MK - 17 (18,1\%). Додатково пластика абсцесу фіброзного кільця МК була проведена $8(8,5 \%)$ пацієнтам. Хірургія клапанів правих відділів серця включала реконструкцію ТК у 31 (33,0\%) випадку, протезування ТK та протезування клапана легеневої артерії склало по одному $(1,1 \%)$ випадку відповідно. Супутні хірургічні корекції виконувалися з приводу ураження вінцевих артерій - 14 (14,9\%) пацієнтів з реваскуляризацією міокарда. Госпітальна летальність склала $3(3,2 \%)$ випадки.

Патоморфологічний i бактеріологічний аналіз отриманого інтраопераційного матеріалу був систематизований відповідно до патоморфологічного критерію. Вегетації та внутрішньосерцеві абсцеси, які демонструють картину активного IE, були підтверджені гістологічно в усіх 94 випадках. Вихідна патологія клапанів, яка сприяла виникненню IE, була діагностована в $80(85,1 \%)$ випадках і включала: ревматизм - $6(7,5 \%)$ випадків, дисплазія клапанних структур - $13(16,3 \%)$ випадків, дегенеративні зміни - $55(68,7 \%)$ випадків. Первинний IE нативних клапанів серця виявлений у 14 (14,9\%) випадках (табл. 3). У 5 (6,3\%) спостереженнях інфекційний процес виник на фоні раніше імплантованих штучних клапанів серця, в одного $(1,2 \%)$ пацієнта - на фоні штучного водія ритму серця.

При мікроскопічних дослідженнях інтраопераційного матеріалу в $19(20,2 \%)$ клапанах виявлено ознаки ліпоїдозу, який міг сприяти проникненню та розмноженню мікрофлори в клапанних структурах. У 18 $(19,1 \%)$ випадках у гістологічних препаратах був виявлений міцелій грибкової мікрофлори. За цією ознакою всі клапани були поділені на дві підгрупи. Першу підгрупу склали клапани, в яких були відсутні ознаки грибкової мікрофлори, - 76 (80,9\%) спостережень. До другої підгрупи - $18(19,1 \%)$ спостережень - увійшли хворі на IE, у яких при патогістологічному обстеженні виявлено міцелій грибкової мікрофлори.

\section{Таблиця 3}

Результати патогістологічних досліджень інтраопераційного матеріалу

\begin{tabular}{lcc} 
& \multicolumn{2}{c}{$\mathbf{N = 9 4}$} \\
\cline { 2 - 3 } Дані дослідження & $\mathbf{n}$ & $\mathbf{\%}$ \\
\hline Первинний IE & 14 & 14,9 \\
\hline Вторинний IE & 80 & 85,1 \\
- ревматизм & 7 & 8,8 \\
- дегенеративні зміни & 52 & 65,0 \\
- дисплазія клапанного апарату & 15 & 18,7 \\
- штучний клапан серця & 5 & 6,3 \\
- штучний водій ритму серця & 1 & 1,2
\end{tabular}


Був проведений аналіз взаємозв'язку клінічних характеристик хворих на IЕ з частотою реєстрації грибкового міцелію в інтраопераційному матеріалі. Обидві підгрупи хворих характеризувалися домінуванням пацієнтів чоловічої статі, при цьому взаємозв'язку гендерних показників із наявністю міцелію в інтраопераційному матеріалі виявлено не було $\left(\mathrm{X}^{2}=0,599, \mathrm{p}=0,439\right)$. Також не виявлено достовірного взаємозв'язку вихідної патології внутрішньосерцевих структур із наявністю грибкового міцелію в гістологічних препаратах $\left(\mathrm{X}^{2}=8,406\right.$, $\mathrm{p}=0,638)$ (табл. 4).

Виявлений взаємозв'язок частоти реєстрації грампозитивних мікроорганізмів з ідентифікацією міцелію грибкової мікрофлори в інтраопераційному матеріалі - $17(20,2 \%)$ випадків $\left(\mathrm{X}^{2}=7,625, \mathrm{p}=0,054\right)$ (табл. 5).

Виявлено, що серед усіх видів грампозитивних збудників найбільш часто поєднувався з реєстрацією міцелію грибкової мікрофлори в інтраопераційному матеріалі (12 (42,9\%) випадків) Enterococcus spp., що ідентифікувався при бактеріологічному дослідженні. Аналогічні поєднання для Staphylococcus spp. та Streptococcus spp. реєструвалися в $3(6,7 \%)$ та $2(20,0 \%)$ спостереженнях відповідно (табл. 6).

Достовірного взаємозв'язку між частотою культивації грамнегативної мікрофлори та виявленням грибкового міцелію в інтраопераційному матеріалі виявлено не було $\left(\mathrm{X}^{2}=0,524, \mathrm{p}=0,427\right)$.

\section{Таблиця 4}

Аналіз взаємозв'язку клінічних характеристик з частотою реєстрації міцелію грибкової мікрофлори в інтраопераційному матеріалі

\begin{tabular}{|c|c|c|c|c|c|}
\hline \multirow[b]{2}{*}{ Показники } & \multirow[b]{2}{*}{$\mathrm{N}=94$} & \multicolumn{2}{|c|}{$\begin{array}{c}\text { Наявність } \\
\text { міцелію }\end{array}$} & \multirow[b]{2}{*}{$\mathbf{X}^{2}$} & \multirow[b]{2}{*}{ p } \\
\hline & & $\mathrm{n}$ & $\%$ & & \\
\hline $\begin{array}{l}\text { Стать: } \\
\text { - чоловіки } \\
\text { - жінки }\end{array}$ & $\begin{array}{l}78 \\
16\end{array}$ & $\begin{array}{c}16 \\
2\end{array}$ & $\begin{array}{l}21,1 \\
12,5\end{array}$ & 0,599 & 0,439 \\
\hline
\end{tabular}

Причини розвитку інфек-

ційного ендокардиту:

- переохолодження

- бронхолегеневі

- урологічні

- стоматологічні

- акушерські

- неврологічні

- наркоманія

- невідомі

Вид клапанних уражень:

- IE AK без абсцесу

- IE AK з абсцесом

- IE MK без абсцесу

- IE MK з абсцесом

- IE ТК та КЛА

Наявність HCV антигену

Наявність HBS антигену

Аналіз взаємозв'язку локалізації IE з частотою реєстрації міцелію грибкової мікрофлори в інтраопераційному матеріалі не показав достовірного результату для клапанів як лівих, так і правих відділів серця. Також нами був проведений окремий аналіз взаємозв'язку абсцесоутворення фіброзного кільця аортального та мітрального клапанів з ідентифікацією міцелію в інтраопераційному матеріалі. При більшій частоті реєстрації абсцесів фіброзного кільця аортального клапана порівняно 3 мітральним ми не виявили достовірного зв'язку з наявністю міцелію в клапанних структурах.

На рівні тенденції виявлено взаємозв'язок причин розвитку IE і частотою реєстрації міцелію грибкової мікрофлори в інтраопераційному матеріалі $\left(\mathrm{X}^{2}=0,352\right.$, $\mathrm{p}=0,171)$. Звертав на себе увагу проведений окремий аналіз для нозокоміальних факторів ризику розвитку IE та наявності ін'єкційної наркоманії. Із 22 випадків госпітального інфікування у $8(36,4 \%)$ випадках спостерігався міцелій у клапанних структурах $\left(\mathrm{X}^{2}=4,956, \mathrm{p}=0,026\right)$. Крім того, розкрито достовірний взаємозв'язок між частотою реєстрації нозокоміального IE та грампозитивним спектром збудників IE. Серед випадків госпітального IE спостерігається найбільша частота інфікування Enterococcus spp. $-13(48,1 \%)$ випадків $\left(\mathrm{X}^{2}=10,1, \mathrm{p}=0,018\right)$ (табл. 7).

Наявність ін'єкційної наркоманії має достовірний взаємозв'язок із реєстрацією міцелію в клапанних структурах $-4(22,2 \%)$ випадки $\left(\mathrm{X}^{2}=4,31, \mathrm{p}=0,038\right)$.

\section{Таблиця $\mathbf{5}$}

Аналіз взаємозв'язку клініко-морфологічних характеристик із частотою реєстрації міцелію грибкової мікрофлори в інтраопераційному матеріалі

\begin{tabular}{|c|c|c|c|c|c|}
\hline \multirow[b]{2}{*}{ Показники } & \multirow[b]{2}{*}{$N=94$} & \multicolumn{2}{|c|}{$\begin{array}{c}\text { Наявність } \\
\text { міцелію }\end{array}$} & \multirow[b]{2}{*}{$\mathbf{X}^{2}$} & \multirow[b]{2}{*}{$\mathbf{p}$} \\
\hline & & $\mathbf{n}$ & $\%$ & & \\
\hline Нозокоміальний IE & 22 & 8 & 36,4 & 4,956 & 0,026 \\
\hline $\begin{array}{l}\text { Вихідна патологія } \\
\text { внутрішньосерцевих } \\
\text { структур: } \\
\text { - первинний IE } \\
\text { - дисплазія } \\
\text { - ревматизм } \\
\text { - дегенеративні зміни } \\
\text { - протезний IE } \\
\text { - електродний IE }\end{array}$ & $\begin{array}{c}14 \\
15 \\
7 \\
52 \\
5 \\
1\end{array}$ & $\begin{array}{c}2 \\
3 \\
1 \\
10 \\
2 \\
0\end{array}$ & $\begin{array}{c}14,3 \\
20,0 \\
14,2 \\
19,2 \\
40,0 \\
-\end{array}$ & 8,406 & 0,638 \\
\hline $\begin{array}{l}\text { Необхідність } \\
\text { гемодіалізу }\end{array}$ & 2 & 1 & 50,0 & 1,061 & 0,303 \\
\hline Емболічні ускладнення & 12 & 3 & 25,0 & 7,191 & 0,304 \\
\hline Абсцес легені & 3 & 2 & 66,7 & 8,365 & 0,067 \\
\hline $\begin{array}{l}\text { Грампозитивний } \\
\text { збудник }\end{array}$ & 84 & 17 & 20,2 & 7,625 & 0,054 \\
\hline $\begin{array}{l}\text { Грамнегативний } \\
\text { збудник }\end{array}$ & 10 & 1 & 10,0 & 0,524 & 0,427 \\
\hline
\end{tabular}




\section{Таблиця 6}

Взаємозв'язок частоти культивації грампозитивних мікроорганізмів із реєстрацією міцелію грибкової мікрофлори в інтраопераційному матеріалі

\begin{tabular}{|c|c|c|c|c|c|c|c|c|c|c|}
\hline \multirow{2}{*}{$\begin{array}{l}\text { Грибкова мікрофлора } \\
\text { при гістологічному } \\
\text { дослідженні }\end{array}$} & \multicolumn{2}{|c|}{ Staphylococcus spp. } & \multicolumn{2}{|c|}{ Streptococcus spp. } & \multicolumn{2}{|c|}{ Enterococcus spp. } & \multicolumn{2}{|c|}{ Micrococcus spp. } & \multicolumn{2}{|c|}{ Разом } \\
\hline & $n$ & $\%$ & $\mathbf{n}$ & $\%$ & $n$ & $\%$ & $\mathrm{n}$ & $\%$ & $\mathbf{n}$ & $\%$ \\
\hline Міцелій (-) & 42 & 93,3 & 8 & 80,0 & 16 & 57,1 & 1 & 100 & 67 & 79,8 \\
\hline Всього & 45 & 100,0 & 10 & 100,0 & 28 & 100,0 & 1 & 100 & 84 & 100,0 \\
\hline
\end{tabular}

\section{Таблиця 7}

Взаємозвязок госпітальних форм IE з частотою реєстрації грампозитивних збудників захворювання

\begin{tabular}{lcccccccc} 
& \multicolumn{3}{c}{ Staphylococcus spp. } & \multicolumn{2}{c}{ Streptococcus spp. } & \multicolumn{2}{c}{ Enterococcus spp. } & \multicolumn{2}{c}{ Micrococcus spp. } \\
\cline { 2 - 9 } Варіант інфікування & $\mathbf{n}$ & $\mathbf{\%}$ & $\mathbf{n}$ & $\mathbf{\%}$ & $\mathbf{n}$ & $\mathbf{\%}$ & $\mathbf{n}$ & $\mathbf{\%}$ \\
\hline Негоспітальний IE & 37 & 12,2 & 10 & 100,0 & 15 & 51,9 & 0 \\
\hline Госпітальний IE & 8 & 17,8 & 0 & - & 13 & 48,1 & 1 \\
\hline Разом & 45 & 100,0 & 10 & 100,0 & 28 & 100,0 & 1
\end{tabular}

При порівняльному аналізі показників системної запальної відповіді виявлено, що хворі з наявністю міцелію в клапанних структурах характеризуються достовірно більшим рівнем C-реактивного протеїну та частоти серцевих скорочень $-158,5 \pm 10,1$ мг/л $(\mathrm{p}=0,024)$ та 99,6 44,3 уд./хв. (p=0,002) відповідно (табл. 8).

В аспекті аналізу виникнення ознак синдрому персистенції інфекції, імуносупресії та катаболізму нами були проаналізовані біохімічні показники функцій паренхіматозних органів та циркулюючого еритрону. Але достовірних відмінностей між підгрупами виявлено не було (табл. 9).

Таким чином, проведене дослідження дозволило виявити групу хворих на IE, в патогенезі захворювання яких беруть участь прокаріоти та еукаріоти. Частота таких випадків становить 19,1\% (18 випадків на

\section{Таблиця 8}

Порівняльний аналіз лабораторних показників синдрому системної запальної відповіді між групами хворих залежно від наявності міцелію грибкової мікрофлори в інтраопераційному матеріалі

\begin{tabular}{lccccc} 
& \multicolumn{2}{c}{$\begin{array}{c}\text { Міцелій } \\
\text { відсутній }\end{array}$} & \multicolumn{2}{c}{$\begin{array}{c}\text { Міцелій } \\
\text { наявний }\end{array}$} & \\
\cline { 2 - 5 } Показники & $\mathbf{M}$ & SD & M & SD & p \\
\cline { 2 - 5 } Лейкоцити (×109) & 10,7 & 0,5 & 11,1 & 0,8 & 0,735 \\
\hline Паличкоядерні (\%) & 17,4 & 0,9 & 18,4 & 2,0 & 0,633 \\
\hline Лімфоцити (\%) & 23,7 & 1,3 & 20,7 & 2,3 & 0,323 \\
\hline ШОЕ (мм/год.) & 24,0 & 2,7 & 20,6 & 2,7 & 0,560 \\
\hline $\begin{array}{l}\text { Прокальцитонін } \\
\text { (нг/мл) }\end{array}$ & 9,5 & 0,7 & 11,0 & 0,5 & 0,621 \\
\hline $\begin{array}{l}\text { С-реактивний } \\
\text { протеїн (мг/л) }\end{array}$ & 53,8 & 11,9 & 158,5 & 10,1 & 0,024 \\
\hline ЧСС (за хв.) & 86,9 & 2,0 & 99,6 & 4,3 & 0,002
\end{tabular}

94 спостереження). Розкрито взаємозв'язок частоти реєстрації грибкового міцелію в клапанних структурах із такими клінічними характеристиками: грампозитивний збудник захворювання, а саме Enterococcus spp. $(p=0,054)$; нозокоміальний варіант інфікування $(\mathrm{p}=0,026)$; на рівні тенденції - гостра інфекційна деструкція легень $(\mathrm{p}=0,067)$.

\section{Висновки}

1. Поєднання прокаріотів та еукаріотів у патогенезі інфекційного ендокардиту зареєстровано в 18 $(19,1 \%)$ випадках.

2. Найбільш часте приєднання грибкової мікрофлори спостерігалось у випадках інфекційного ендокардиту, спричиненого Enterococcus spp., - 42,9\% випадків.

3. Нозокоміальний IE становить $22(23,4 \%)$ випадки. При цьому частота реєстрації Enteroc. spp. є найбільшою $-48,1 \%$ випадків $(p=0,018)$.

\section{Таблиця 9}

Порівняльний аналіз біохімічних показників крові між групами хворих залежно від наявності міцелію грибкової мікрофлори в інтраопераційному матеріалі

\begin{tabular}{lccccc} 
& \multicolumn{2}{c}{$\begin{array}{c}\text { Міцелій } \\
\text { відсутній }\end{array}$} & \multicolumn{2}{c}{$\begin{array}{c}\text { Міцелій } \\
\text { наявний }\end{array}$} & \\
\cline { 2 - 5 } Показники & $\mathbf{M}$ & $\mathbf{S D}$ & $\mathbf{M}$ & $\mathbf{S D}$ & $\mathbf{p}$ \\
\hline Гемоглобін (г/л) & 111,5 & 2,5 & 110,8 & 3,9 & 0,900 \\
\hline Еритроцити (*1012) & 3,6 & 1,8 & 3,8 & 0,1 & 0,470 \\
\hline Тромбоцити (“109) & 229,4 & 12,1 & 236,7 & 35,4 & 0,809 \\
\hline Сечовина (ммоль/л) & 8,2 & 0,1 & 7,2 & 0,9 & 0,612 \\
\hline Креатинін (мкмоль/л) & 103,4 & 6,0 & 125,3 & 28,2 & 0,235 \\
\hline Білірубін (ммоль/л) & 15,6 & 1,2 & 18,7 & 2,8 & 0,268 \\
\hline Глюкоза (ммоль/л) & 6,1 & 0,2 & 6,2 & 0,3 & 0,691
\end{tabular}


4. Грампозитивні збудники IE найчастіше поєднуються з реєстрацією грибкової мікрофлори в інтраопераційному матеріалі - 20,0\% випадків ( $\mathrm{p}=0,054)$.

5. Виявлено взаємозв'язок між реєстрацією міцелію в інтраопераційному матеріалі і такими клінічними характеристиками: нозокоміальні фактори $(\mathrm{p}=0,026)$, гостра інфекційна деструкція легень $(\mathrm{p}=0,067)$, наркоманія $(\mathrm{p}=0,038)$.

\section{Література}

1. Shi-Min Yuan. Fungal Endocarditis // Braz J. Cardiovasc Surg. - 2016. - Vol. 31 (3). - P. 252-255.

2. Comparison of characteristics and short-term outcome from fungal infective endocarditis in prosthetic valve endocarditis versus native valve endocarditis / Sun X., Zhang J, Wang G. et al. // Am J Cardiol. - 2013. - Vol. 112 (1). - P. 111-116.

3. A distinctly rare case of candida endocarditis involving the bioprosthetic pulmonary and the Eustachian valve diagnosed on 3D transesophageal echocardiography / Pasha A., Snyder B., Zangeneh T. et al. // Echocardiography. 2015. - Vol. 32 (3). - P. 607-609.
4. Fungal Endocarditis: Update on Diagnosis and Management / Ahmed K., Justin Z., See-Wei L. et al. // The American Journal of Medicine. - 2016. - Vol. 129. P. 1037-1043.

5. Fungal endocarditis: current challenges / Pierre T., Matthieu R., Agnus L. et al. // International Journal of Antimicrobial Agents. - 2014. - Vol. 44. - P. 290-294.

6. Native aortic valve fungal endocarditis / Shyam Chand Chaudhary, Kamal Kumar Sawlani, Rahul Arora // BMJ Case Rep. - 2013. - Feb 20. doi: 10.1136/bcr-2012-007144

7. Contemporary clinical profile and outcome of prosthetic valve endocarditis / Wang A., Athan E., Pappas P. et al. // Jama. - 2007. - Vol. 297 (12). -P. 1354-1361.

8. Comparison of caspofungin and amphotericin $\mathrm{B}$ for invasive candidiasis / Mora-Duarte J., Betts R., Rotstein C. et al. // The New England journal of medicine. - 2002. - Vol. 347 (25). - P. 2020-2029.

9. Fatal fungal endocarditis by Aspergillus udagawae: an emerging cause of invasive aspergillosis / Atsuko S., Atsushi Y., Yoko M. et al. // Cardiovascular Pathology. 2017. - Vol. 28. - P. 14-17.

\title{
Clinical and morphological interaction of the combination of prokaryotes with fungal microflora in pathogenesis of infective endocarditis
}

\author{
Krykunov O. A., Zakharova V. P., Buryak R. V., Koltunova A. B., Rusnak A. O., Khmelevsky A. M. \\ National M. M. Amosov Institute of Cardiovascular Surgery National Academy of Medical Sciences of Ukraine (Kyiv)
}

The peculiarity of fungal infective endocarditis (IE) is manifestation of the disease on the background of significant damage of the patients' immunological status, also due to corticosteroid or cytostatic therapy. Combination of fungal microflora with ESCAPE group microorganisms makes treatment of IE more complicated. Odjectives: to investigate the clinical features of combination of prokaryotes with fungal microflora in the pathogenesis of IE. Materials and methods. The basis of this study was clinical data of 94 patients with active infective endocarditis, who were examined and surgically treated at the Amosov National Institute of Cardiovascular Surgery NAMS of Ukraine from 01.01.2014 to 01.12.2016 y. Results and discussion. The rates of gram-positive and gram-negative microorganisms were: $84(89,4 \%)$ cases and $10(10,6 \%)$ cases, respectively. Combination of prokaryotes and eukaryotes in the pathogenesis of infective endocarditis has been reported in 18 (19.1\%) cases. Supplementation of fungal microflora was observed in cases of IE caused by Enterococcus spp. $-42.9 \%$ of cases. Among 22 cases of hospitalacquired IE in 8 (36.4\%) cases, fungal mycelium was observed in the valve structures $\left(X^{2}=4.956, p=0.026\right)$.

Key words: infective endocarditis, fungal microflora, prokaryotes.

\section{Клинико-морфологические взаимосвязи сочетания прокариот с грибковой микрофлорой в патогенезе инфекционного эндокардита}

\author{
Крикунов А. А., Захарова В. П., Буряк Р. В., Колтунова А. Б., Руснак А. О., Хмелевский А. Н. \\ ГУ «Национальный институт сердечно-сосудистой хирургии имени Н. М. Амосова НАМН» (Киев)
}

Особенностью инфекционного эндокардита (ИЭ) микотического генеза является манифестация заболевания на фоне значительного повреждения иммунологического состояния больных, в том числе и вследствие терапии кортикостероидами или цитостатиками. Еще больше осложняет лечение ИЭ сочетание грибковой микрофлоры с микроорганизмами группы ESCAPE. Цель работы - исследовать клинические особенности сочетания прокариот с грибковой микрофлорой в патогенезе ИЭ. Материалы и методы. Основу данного исследования составляют клинические данные 94 больных активным инфекционным эндокардитом, прошедших обследование и лечение в Национальном институте сердечно-сосудистой хирургии имени Н. М. Амосова НАМН с 01.01.2014 по 01.12.2016 г. Результаты и их обсуждение. Частота регистрации грамположительных и грамотрицательных микроорганизмов составила $84(89,4 \%)$ и $10(10,6 \%)$ случаев соответственно. Сочетание прокариот и эукариот в патогенезе инфекционного эндокардита зарегистрировано в $18(19,1 \%)$ случаях. Идентификация грибковой микрофлоры чаще всего наблюдалось в случаях инфекционного эндокардита, вызванного Enterococcus spp., $-42,9 \%$ случаев. Из 22 случаев госпитального ИЭ в $8(36,4 \%)$ случаях в клапанных структурах был выявлен мицелий грибов $(\mathrm{X} 2=4,956, \mathrm{p}=0,026)$.

Ключевые слова: инфекционный эндокардит, грибковая микрофлора, прокариоты. 